The University of San Francisco

USF Scholarship: a digital repository @ Gleeson Library | Geschke Center

Gleeson Library Faculty and Staff Research and

Scholarship

Gleeson Library | Geschke Center

$12-2017$

\title{
Critical Appraisal Tools and Reporting Guidelines for Evidence-Based Practice
}

Robin Buccheri

University of San Francisco

Claire Olivia Sharifi

University of San Francisco, cosharifi@usfca.edu

Follow this and additional works at: https://repository.usfca.edu/librarian

Part of the Library and Information Science Commons, and the Nursing Commons

\section{Recommended Citation}

Buccheri, R. K., \& Sharifi, C. (2017). Critical appraisal tools and reporting guidelines for evidence-based practice. Worldviews on Evidence-Based Nursing, (6), 463. https://doi.org/10.1111/wvn.12258

This Article is brought to you for free and open access by the Gleeson Library | Geschke Center at USF Scholarship: a digital repository @ Gleeson Library | Geschke Center. It has been accepted for inclusion in Gleeson Library Faculty and Staff Research and Scholarship by an authorized administrator of USF Scholarship: a digital repository @ Gleeson Library | Geschke Center. For more information, please contact repository@usfca.edu. 


\section{Critical Appraisal Tools and Reporting Guidelines for Evidence-Based Practice}

Buccheri, R. K., \& Sharifi, C. (2017). Critical Appraisal Tools and Reporting Guidelines for Evidence-Based Practice. Worldviews on Evidence-Based Nursing, 14(6), 463-472. https://doi.org/10.1111/wvn.12258

Robin Buccheri, PhD, RN, NP, FAAN, Professor (Corresponding Author)

School of Nursing \& Health Professions

Cowell Hall \#222

University of San Francisco

2130 Fulton Street

San Francisco, CA

buccherir@usfca.edu

(415) 497-0651 (cell)

Claire Sharifi, BS, MLIS, Reference Librarian

Primary Liaison: School of Nursing \& Health Professions

Gleeson Library

University of San Francisco

2130 Fulton Street

San Francisco, CA 94117

cosharifi@usfca.edu

(415) 422-5399 


\section{Critical Appraisal Tools and Reporting Guidelines for Evidence-Based Practice Introduction}

Nurses engaged in evidence-based practice have two important sets of tools: (a) critical appraisal tools that aid in assessing evidence for validity, reliability and applicability to clinical practice, and (b) reporting guidelines that aid in the structured, comprehensive and transparent dissemination of outcomes and findings during the publication process. Both critical appraisal tools and reporting guidelines are distinct entities and each is essential to evidence-based practice. Selecting the most appropriate critical appraisal tool or reporting guideline can be very challenging for both novice and expert consumers of evidence.

The primary purpose of this paper is to help nurses understand the difference between critical appraisal tools and reporting guidelines. A second purpose is to help them find the appropriate tool for the job, whether that job is the critical appraisal of evidence or reporting the results of an evidence-based practice project, a research study, or a clinical practice guideline.

This article provides definitions and descriptions of critical appraisal tools and reporting guidelines and rationales for their use. A selection of frequently used critical appraisal tools and reporting guidelines are described and instructions are provided for selecting the most appropriate tools. Information on how to access the full text of selected critical appraisal tools and reporting guidelines is provided as well as examples of each tools use in a publication.

\section{Background}

\section{Rationale for Using Critical Appraisal Tools}

In order to answer a clinical question to improve practice, nurses must be able to evaluate the body of evidence on a topic. Critical appraisal, defined by Duffy (2005) as "an objective, structured approach that results in a better understanding of a study's strengths and weaknesses" 
(p. 282), is the process that allows the nurse to identify evidence that comes from rigorous, reliable, unbiased, and methodologically appropriate research (Melnyk \& Fineout-Overholt, 2015).

Critical appraisal tools allow nurses to evaluate the evidence using structured questions and/or a checklist. However, they are not a one-size-fits-all resource and nurses often turn to a familiar critical appraisal tool, regardless of whether or not it is the most appropriate tool for the methodology of the article they are reviewing. Compounding the problem is the lack of a "gold standard" critical appraisal tool and the sheer volume of available tools. This can make matching the tool to the type of evidence problematic, particularly for novice consumers of evidence (Katrak et al., 2004).

Having the skills to select the appropriate tool or guideline is an essential part of meeting evidence-based practice (EBP) competencies for both practicing registered nurses and advanced practice nurses (Melnyk, \& Gallagher-Ford, 2015; Melnyk, Gallagher-Ford, \& Fineout-Overholt, 2017). Critical appraisal is an EBP competency for both practicing registered nurses and advanced practice nurses (Melnyk, Gallagher-Ford, Long, \& Fineout-Overholt, 2014). In order to educate nurses to evaluate a body of literature and translate research into practice, academic institutions must lay the foundation by teaching students to critically appraise research and other types of evidence using the tools available.

\section{Rationale for Using Reporting Guidelines in Publishing}

Reporting guidelines — checklists of items that researchers should include in a publication, ensure that the research process, evidence-based practice projects, and clinical practice guidelines are reported on with clarity and in a manner that allows for critical appraisal. Reporting guidelines often specify a minimum set of items that need to be reported in order to 
provide a clear and transparent account of the research process and study findings (National Library of Medicine, 2015).

Opaque reporting is directly associated with biased conclusions and, less directly, with errors in biomedical publishing and the inefficient use of scarce resources. As Moher, Altman, Schulz, Simera, and Wager (2014) state, "without a clear understanding of how a study was done, readers are unable to judge whether the findings are reliable" (p. 4). A systematic review by Samaan et al. (2013) found that adherence to reporting guidelines in the medical literature was suboptimal and they recommended that educators incorporate guidelines into the curriculum to increase the amount of medical literature that adheres to reporting guidelines. Incorporating reporting guidelines into nursing education would help registered and advanced practice nurses achieve EBP competencies related to disseminating the evidence (Melnyk et al., 2017).

\section{Search Methodology}

One author amassed a bibliography of critical appraisal tools and reporting guidelines during her eight years of teaching evidence-based practice at the doctoral level. The collection was expanded through conference attendance, reviewing evidence-based practice textbooks, and networking with other evidence-based practice nurse educators. Next, both authors collaborated on a comprehensive search to validate the list and to identify other commonly used critical appraisal tools and reporting guidelines. PubMed, CINAHL and Scopus were searched using a combination of keywords and subject headings for the following concepts: critical appraisal, critique tool, and reporting guidelines.

Nine critical appraisal tools and eight reporting guidelines were selected based on their relevancy to nursing, their ease of use, and their reported frequency of use. The literature discussing the development and use of each selected tool and guideline was reviewed. A brief 
synopsis of each tool was developed, along with tables to help select the appropriate tool/guideline, information about how to access the full text of the tool/guideline, and an example of the tool/guideline in a publication. Where one tool serves both functions-a tool that was developed to be a critical appraisal tool and a reporting guideline, we have noted it and included the tool in both categories.

\section{Critical Appraisal Tools}

\section{Selecting a Critical Appraisal Tool}

The following steps provide a roadmap for selecting an appropriate critical appraisal tool.

1. Determine the type of evidence to be appraised. Prioritize pre-appraised evidence (systematic review, meta-analysis, meta-synthesis, clinical practice guidelines) over individual primary research studies (Melnyk, Gallagher-Ford \& Fineout-Overholt, 2017).

2. Go to table 1 and identify the tools appropriate for that type of evidence [see appendix].

3. Read the brief summaries on relevant tools and select one.

4. Go to table 2 [see appendix] to locate the full text of the tool and a citation for an article that demonstrates the tool in use.

\section{Summaries of Selected Critical Appraisal Tools}

Below is a brief description of eight frequently used critical appraisal tools that are also displayed in table 1[see appendix]. Information on how to access each critical appraisal tool and an example of each tool's use in an article are included in table 2 [see appendix].

\section{AGREE II: Appraisal of Guidelines for Research and Evaluation II}

The AGREE II instrument is a critical appraisal tool specifically for clinical practice guidelines. It was first developed in 2003 by the AGREE collaboration, an international group of guideline developers. The original instrument was refined and AGREE II was released in 2010 
(Brouwers et al., 2010). The AGREE II can be used as a quality assessment tool for readers of clinical guidelines. The checklist covers six quality domains and each domain has between 2 and 6 questions. The Agree II can be found at: http://www.agreetrust.org/resource-centre/

\section{CASP checklists: Critical Appraisal Skills Programme checklists}

CASP checklists were developed in 1993 and are a product of the Critical Appraisal Skills Programme from Oxford, England. CASP checklists are critical appraisal tools, and CASP offers checklists for the following 8 types of research: systematic reviews, randomized controlled trials, diagnostic studies, economic evaluations, qualitative research, case control studies, cohort studies, and clinical prediction rules ("Critical Appraisal Skills Programme", 2017). The checklists all have between 10 and 12 yes/no items with some open-ended questions. These checklists were developed for use in educational workshops and may be challenging for novices working independently. The various CASP checklists can be found at: http://www.casp$\underline{\text { uk.net/\#!casp-tools-checklists/c18f8 }}$

\section{Cochrane Risk of Bias Tool}

This tool was developed to assess the risk of bias in each study reported in a Cochrane Systematic Review. Bias occurs when, because of methodological flaws, authors overestimate or underestimate the effect of interventions. Bias can affect the validity of study findings. In clinical trials, common types of bias include selection bias, performance bias, detection bias, attrition bias, and reporting bias (Higgins \& Green, 2011). Unlike many of the other tools described in this paper, the Cochrane Risk of Bias Tool supports just one column in an evidence table - the risk of bias column. The Cochrane Risk of Bias Tool includes 7 items, and each item has a "Support for Judgment" field that provides background information on how to evaluate that item, and a "Review Authors' Judgment" field that includes examples of language that can be included 
in an evidence table. The Cochrane Risk of Bias Tool is published in chapter 8 of the Cochrane Handbook for Systematic Reviews of Interventions and can be found at:

http://handbook.cochrane.org/chapter $8 /$ table 85 a the cochrane collaborations tool for ass essing.htm

\section{EPQA Guidelines: Evidence-based Process Quality Assessment Guidelines}

EPQA Guidelines, created in 2013 by a group of national nursing evidence-based practice experts, address publications that report on evidence-based projects (Lee, Johnson, Newhouse, \& Warren, 2013). EPQA is a response to both the proliferation of publications reporting on evidence-based practice projects, as well as the lack of a critical appraisal tools and reporting guideline tools for evidence-based practice projects. The EPQA Guidelines checklist is based on the PRISMA Tool, but with specific edits to make it applicable to publications that discuss evidence-based practice projects. The checklist contains 34 items and can be used either as a reporting guideline for authors writing an evidence-based practice report or as a critical appraisal

tool for readers of evidence-based practice project reports. More information about EPQA can be found at: http://www.ncbi.nlm.nih.gov/pubmed/23387900

\section{GRADE: Grading of Recommendations Assessment, Development, and Evaluation}

GRADE was developed by an international panel in 2011 (Dijkers, 2013). GRADE was designed to provide one systematic approach for evaluating the quality of medical evidence and grading the strength of recommendations in systematic reviews, health technology assessments (HTAs), and clinical practice guidelines (CPGs) (Guyatt et al. 2011). The goal was to reduce bias and assist in the development of "expert created medical guidelines" (Grade Working Group website). GRADE guidelines outline criteria for grading the quality of evidence for each study outcome, upgrading and downgrading evidence, and for rating the overall quality of the 
evidence. GRADE has been adopted for use by organizations such as the Cochrane Collaboration and the World Health Organization (Dijkers, 2013). GRADE is part of GRADEpro, software package for guideline development and adoption. More information about GRADE can be found at: http://www.gradeworkinggroup.org/

\section{Joanna Briggs Institute (JBI): Critical Appraisal Tools}

Joanna Briggs Institute (JBI), an international organization dedicated to the promotion and adoption of evidence-based practice, offers a selection of critical appraisal tools (Joanna Briggs Institute, 2016). There are 13 tools, each of which addresses a specific type of study or other form of evidence. Each tool contains an introduction to JBI and a checklist followed by an indepth explanation of each question. Each checklist contains a series of critical appraisal questions and ends with an overall appraisal decision. The questions and explanations are clearly written and could be utilized by novice consumers of evidence. The checklists can be found at: http://joannabriggs.org/research/critical-appraisal-tools.html

\section{Johns Hopkins Research Evidence Appraisal Tool}

The Johns Hopkins Research Evidence Appraisal Tool (Dearholt \& Dang, 2012) is a tool and rating scale that facilitates the critical appraisal of evidence. It is a commonly used tool appropriate for both novice and expert consumers of evidence. The Research Evidence Appraisal Tool includes questions that facilitate the evaluation of the study design/level of evidence. The tool asks users to answer three fairly simple questions, the answers to which allow users to determine the methodology of the study, and hence the level of evidence. Levels of evidence range from I (RCT) to III (non-experimental/qualitative). The tool also includes a section on appraising systematic reviews, meta-analysis, and meta-synthesis. The next section of the tool walks users through appraising the quality of the research study through the use of a 16-item 
checklist for research studies and a 12-item checklist for systematic reviews, meta-analyses, or meta-syntheses. More information, as well as permissions and the full text of the JHNEB tools can be found at: http://www.hopkinsmedicine.org/evidence-based-practice/jhn ebp.html

\section{Johns Hopkins Non-Research Evidence Appraisal Tool}

The John Hopkins Non-Research Evidence Appraisal Tool (Dearholt \& Dang, 2012) first guides users through identifying what type of non-research item they are reading - a clinical practice guideline, a consensus/policy statement, a literature review, an expert opinion piece, an organizational experience, a case report, or a community standard/clinician experience/consumer preference article. Within each non-research item subsection there is an evaluation checklist. It is an appropriate tool for both novice and expert consumers of evidence. More information, as well as permissions and the full text of the JHNEB tools can be found at: http://www.hopkinsmedicine.org/evidence-based-practice/jhn ebp.html

\section{Rapid Critical Appraisal Checklists: Evidence-Based Practice in Nursing \& Healthcare}

Melnyk and Fineout-Overholt's third edition of Evidence-Based Practice in Nursing \& Healthcare (2015) contains a series of Rapid Critical Appraisal Checklists, all of which are appropriate tools for novice and expert consumers of evidence. There is a General Appraisal Overview for All Studies that contains fields for the article citation, the Population, Intervention, Comparison, Outcome, Timeframe (PICOT) question (Melynyk \& Fineout-Overholt, 2015), and a very general overview of the study (purpose, design, sampling, etc.). This general appraisal form is followed by rapid critical appraisal checklists for the following types of literature: descriptive studies, evidence-based practice implementation or quality improvement projects, cohort studies, randomized controlled trials, systematic reviews of clinical interventions/treatments, qualitative evidence, and evidence-based guidelines. The checklists 
contain between 3 and 32 items. The checklists can be found in the $3^{\text {rd }}$ edition of Evidence-Based Practice in Nursing \& Healthcare: https://www.lww.com/Product/9781451190946

\section{Reporting Guidelines}

\section{Selecting a Reporting Guideline}

The following steps provide a roadmap for selecting an appropriate reporting guideline.

1. Determine the type of evidence to be disseminated.

2. Go to table 3 [see appendix]. and identify the appropriate guideline to report that type of evidence.

3. Read the brief summary of the relevant reporting guideline.

4. Go to table 4 [see appendix] to locate the full text of the reporting guideline and a citation for an article using this guideline.

\section{Summaries of Selected Reporting Guidelines}

Below is a brief of description of eight guidelines that nurses are likely to encounter. The guidelines below are listed in Table 3 [see appendix].

\section{AGREE Reporting Checklist: Appraisal of Guidelines for Research and Evaluation}

The AGREE Reporting Checklist was developed to improve the comprehensiveness, completeness, and transparency of practice guidelines (Brouwers, Kerkvliet, \& Spithoff, 2016). The 23-item checklist aligns with the structure of the AGREE II and retains its six quality domains. The checklist can be found at: http://www.agreetrust.org/resource-centre/agreereporting-checklist/

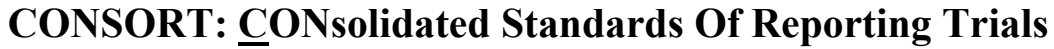

CONSORT was developed to provide standardized guidelines for the transparent reporting of randomized clinical trials (Turner et al., 2012). It consists of a 25 -item checklist that provides 
detailed information to be reported under six categories (title and abstract, introduction, methods, results, discussion and other information) and a flow diagram that includes 4 categories (enrollment, allocation, follow-up and analysis). It asks for the specific number of subjects who participated from initial assessment of eligibility to number of subjects included and excluded in the final analysis, and reasons for inclusion and exclusion. The checklist can be found at: http://www.consort-statement.org/

\section{COREQ: COnsolidated criteria for REporting Qualitative research}

The COREQ is a checklist developed as a reporting guideline for the explicit and comprehensive reporting of qualitative studies that use in-depth interviews and focus groups (Tong, Sainsbury, \& Craig, 2007). The 32-item checklist covers three domains: research team and reflexivity, study design, and analysis and findings. The checklist was developed from a comprehensive search for existing guidelines to assess qualitative research reports. The authors reported finding no comprehensive reporting checklist for qualitative research so items retrieved were compiled into the COREQ. More information on the checklist can be found at: http://www.equator-network.org/reporting-guidelines/coreq

\section{EPQA Guidelines: Evidence-based Process Quality Assessment}

EPQA Guidelines, created in 2013 by a group of national nursing evidence-based practice experts, specifically address publications that report on evidence-based projects (Lee, Johnson, Newhouse, \& Warren, 2013). EPQA Guidelines are a response to both the proliferation of publications reporting on evidence-based practice projects, as well as the lack of critical appraisal tools and reporting guideline tools for evidence-based practice projects. The EPQA Guidelines checklist is based on the PRISMA Tool, but with specific edits to make it applicable to publications that discuss evidence-based practice projects. The checklist contains 34 items and 
can be used either as a reporting guideline for authors writing an evidence-based practice report, or as a critical appraisal tool for readers of evidence-based practice project reports. More information about EPQA Guidelines can be found at:

http://www.ncbi.nlm.nih.gov/pubmed/23387900

ENTREQ: ENhancing Transparency in REporting the synthesis of Qualitative research ENTREQ reporting guideline was created in 2012 (Tong, Fleming, McInnes, Oliver, \& Craig. 2012). ENTREQ provides a reporting guideline for meta-synthesis articles-articles that synthesize qualitative research. The ENTREQ reporting guideline consists of 21 items that are grouped into five distinct domains: introduction, methods \& methodology, literature search \& selection, appraisal, and synthesis of findings. ENTREQ reporting guideline can be found at: http://bmcmedresmethodol.biomedcentral.com/articles/10.1186/1471-2288-12-181

PRISMA: Preferred Reporting Items for Systematic reviews and Meta-Analyses Statement

The PRISMA Statement was developed in 2009 by an international group of researchers who revised the QUOROM Statement (QUality Of Reporting Of Meta-analyses) to include systematic reviews (Moher, 2009). PRISMA consists of a flow diagram, and a checklist of 27 items that are essential to clear, transparent systematic review reporting (Moher, 2009). PRISMA is a tool authors can use to improve the reporting quality of their systematic reviews and metaanalyses. Improved reporting of systematic reviews and meta-analyses results in increased transparency, and allows readers to more effectively evaluate the quality and findings of these publications (Moher, 2009; Liberati, 2009). More information on PRISMA can be found at: https://www.ncbi.nlm.nih.gov/pubmed/19621072.

SQUIRE 2.0: revised Standards for QUality Improvement Reporting Excellence 
SQUIRE guidelines were developed to provide a framework for authors reporting results of system level approaches designed to improve healthcare (quality, safety, value). The most recent version, SQUIRE 2.0, includes 18 categories (each with multiple items) that should all be considered but are not all applicable to every report (Ogrinc, Davies, Goodman, Batalden, Davidoff, \& Stevens, 2015). The SQUIRE 2.0 Explanation and Elaboration with examples, the Guidelines, and the Checklist can all be found at: http://www.squire-statement.org STROBE Guidelines: STrengthening the Reporting of OBservational studies in

\section{Epidemiology}

The STROBE Guidelines were created in 2007 by an international group of epidemiologists, methodologists, statisticians, researchers and journal editors (Vandenbroucke et al., 2007). STROBE Guidelines are intended to strengthen the reporting of observational epidemiological studies (Vandenbroucke et al., 2007). Specifically, STROBE checklists exist for cohort studies, case-control studies, and cross-sectional studies (Vandenbroucke et al., 2007). STROBE also makes available an Explanation and Elaboration article which discusses each checklist item and provides examples of transparent reporting. The Explanation and Elaboration article can be found at: http://journals.plos.org/plosmedicine/article?id=10.1371/journal.pmed.0040297 and the full text of all checklists can be found at: http://www.strobe$\underline{\text { statement.org/index.php?id=available-checklists }}$

\section{Additional Reporting Guideline Resource}

In addition to the selected guidelines summarized above, Enhancing the QUAlity and Transparency Of health Research (EQUATOR Network) is a useful resource for identifying additional reporting guidelines. The EQUATOR Network, founded in 2006 and funded by the UK National Health Services (NHS) National Knowledge Service, currently maintains a library 
that contains over 200 reporting guidelines (Moher, Altman, Schulz, Simera, \& Wager, 2014). Additionally, the EQUATOR Network provides extensive toolkits to improve the reporting of health research studies and can be found at: http://www.equator-network.org .

\section{Summary and Conclusion}

Critical appraisal tools help nurses move from subjective evaluation toward a more objective and analytical assessment of evidence. Reporting guidelines improve both transparency and the quality of publications and reports. Together these tools help nurses attain evidence-based practice competencies (Melnyk, Gallagher-Ford, \& Fineout-Overholt, 2017) as well as improve general critical thinking skills (Whiffin \& Hasselder, 2013).

While critical appraisal tools and reporting guidelines are useful tools that have the potential to improve scholarship and evidence-based practice, identifying and selecting the appropriate tool is a potentially challenging and frustrating experience for both novice and expert consumers and reporters of evidence. By providing clear descriptions of each tool, as well as tables that provide easy reference for matching the type of tool with an article's methodology, this article lessens that challenge and minimizes frustration.

Facilitating the selection of appropriate critical appraisal tools and reporting guidelines is useful to nurses with varying levels of competency in EBP. Nurses who are just learning how to critically appraise research and other types of evidence will find the overview of the different types of critical appraisal tools particularly useful. For those with more advanced EBP competencies, this article will serve as both a resource for selecting a critical appraisal tool that can be used during the evidence review process, and as resource for identifying reporting guidelines for use when writing up reports to disseminate evidence. 


\section{LINKING EVIDENCE TO ACTION}

- Practicing registered nurses and advanced practice nurses must be able to critically appraise and disseminate evidence in order to meet evidence-based practice competencies.

- Differentiating between a critical appraisal tool and a reporting guideline is an essential EBP skill, as is selecting the appropriate tool/guideline.

- This article is a resource for understanding the difference between critical appraisal tools and reporting guidelines, and identifying and accessing appropriate tools/guidelines.

- Selecting the appropriate critical appraisal tool or reporting guideline has the potential to make the critical appraisal and publishing processes more effective and less frustrating and laborious.

- Increased use of critical appraisal tools and reporting guidelines will support EBP and improve nursing practice. 


\section{References}

Brouwers, M. C., Kerkvliet, K., \& Spithoff, K. on behalf of the AGREE Next Steps Consortium. (2016). The AGREE Reporting Checklist: A tool to improve reporting of clinical practice guidelines. British Medical Journal, 352(3), 482. doi: 10.1136/bmj.i1152

Brouwers, M., Kho M. E., Browman, G. P., Burgers, J. S., Cluzeau F., Feder G.,... Zitzelsberger, L. for the AGREE Next Steps Consortium (2010). AGREE II: Advancing guideline development, reporting and evaluation in healthcare. Canadian Medical Association Journal, 182, 839-842. doi:10.1503/090449

Critical Appraisal Skills Programme (2017). CASP checklists. Retrieved from: http://www.caspuk.net/checklists

Dearholt, S., \& Dang, D. (2012). Johns Hopkins nursing evidence-based practice: Models and guidelines $\left(2^{\text {nd }}\right.$ ed.). Indianapolis, IN: Sigma Theta Tau International.

Consort: Transparent Reporting of Trials. (n.d.) Welcome to the CONSORT website. Retrieved from http://www.consort-statement.org/

Dijkers, M. (2013). Introducing GRADE: A systematic approach to rating evidence in systematic reviews and to guideline development. KT Update (An e-newsletter from the Center on Knowledge Translation for Disability and Rehabilitation Research), 1(5). [http://www.ktdrr.org/products/update/v1n5/]

Duffy, J. R. (2005). Critically appraising quantitative research. Nursing and Health Sciences, 7(4), 281-283. http://doi.org/10.1111/j.1442-2018.2005.00248.x 
Guyatt, G., Oxman, A.D., Akl, E.A., Kunz, R., Vist, G., Brozek, J.,...Schunemann, H.J. (2011). GRADE Guidelines: 1. Introduction—GRADE evidence profiles and summary of findings tables. Journal of Clinical Epidemiology 64, 383-394.

Grade Working Group website: http://www.gradeworkinggroup.org/index.htm

Higgins, J. P. T., \& Altman, D. G., \& Sterne, J. A. C. (2011). Assessing risk of bias in included studies. In J. P. T. Higgins, \& S. Green (Eds.). Cochrane handbook of systematic reviews of interventions (Version 5.1.0). Cochrane Collaboration. http://handbook.cochrane.org

Joanna Briggs Institute (JBI) (2016). Critical Appraisal Tools. Retrieved from http://joannabriggs.org/research/critical-appraisal-tools.html

Katrak, P., Bialocerkowski, A. E., Massy-Westropp, N., Kumar, V. S., \& Grimmer, K. A. (2004). A systematic review of the content of critical appraisal tools. BMC Medical Research Methodology, 4, 22. http://doi.org/10.1186/1471-2288-4-22

Lee, M. C., Johnson, K. L., Newhouse, R. P., \& Warren, J. I. (2013). Evidence-based Practice Process Quality Assessment: EPQA Guidelines. Worldviews on Evidence-Based Nursing, 10(3), 140-149. http://doi.org/10.1111/j.1741-6787.2012.00264.x

Liberati, A., Altman, D. G., Tetzlaff, J., Mulrow, C., Gøtzsche, P. C., Ioannidis, J. P. A., ... Moher, D. (2009). The PRISMA statement for reporting systematic reviews and metaanalyses of studies that evaluate healthcare interventions: explanation and elaboration. $B M J$, 339, b2700. http://doi.org/10.1136/bmj.b2700

Melnyk, B. M., \& Gallagher-Ford (2015). Implementing the new essential evidence-based competencies in real-world clinical and academic settings: Moving from evidence to action in improving healthcare quality and patient outcomes (Editorial). Worldviews on EvidenceBased Nursing, 12(2), 67-69. 
Melnyk, B. M., \& Fineout-Overholt, E. (2015). Evidence-based practice in nursing and healthcare: A guide to best practice. Philadelphia: Wolters Kluwer Health.

Melnyk, B. M., Gallagher-Ford, L., \& Fineout-Overholt. (2017). Implementing the evidencebased practice (EBP) competencies in healthcare. Indianapolis: IN: Sigma Theta Tau

Melnyk, B. M., Gallagher-Ford, L., Long, L. E., \& Fineout-Overholt, E. (2014). The establishment of evidence-based practice competencies for practicing registered nurses and advanced practice nurses in real-world clinical settings: Proficiencies to improve healthcare quality, reliability, patient outcomes, and costs. Worldviews on Evidence-Based Nursing, $11(1), 5-15$.

Moher, D., Altman, D. G., Schulz, K. F., Simera, I., \& Wager, E. (2014). Guidelines for reporting health research: A user's manual. Chichester, West Sussex; 4: Wiley Blackwell.

Moher, D., Liberati, A., Tetzlaff, J., Altman, D. G., \& The PRISMA Group. (2009). Preferred Reporting Items for Systematic Reviews and Meta-Analyses: The PRISMA Statement. PLoS Med, 6(7), e1000097. http://doi.org/10.1371/journal.pmed.1000097

National Library of Medicine. (2015). Research Reporting Guidelines and Initiatives: By Organization. Retrieved from https://www.nlm.nih.gov/services/research_report_guide.html Ogrinc, G., Davies, L., Goodman, D., Batalden, P., Davidoff, F., Stevens, D., . . Wollersheim, H. (2015). SQUIRE 2.0 (Standards for QUality Improvement Reporting Excellence): Revised publication guidelines from a detailed consensus process. BMJ Quality \& Safety, , 004411. doi:10.1136/bmjqs-2015-004411

Samaan, Z., Mbuagbaw, L., Kosa, S., Borg Debono, V., Dillenburg, R, Zhang, S.,... Thibane, L. (2013). A systematic scoping review of adherence to reporting guidelines in health care 
literature. Journal of Multidisciplinary Healthcare, 169-188.

http://doi.org/10.2147/JMDH.S43952

SQUIRE 2.0.SQUIRE | SQUIRE 2.0 guidelines. Retrieved from http://www.squirestatement.org/index.cfm?fuseaction=Page.ViewPage\&PageID=471

Tong, A., Flemming, K., McInnes, E., Oliver, S., \& Craig, J. (2012). Enhancing transparency in reporting the synthesis of qualitative research: ENTREQ. BMC Medical Research Methodology, 12, 181. http://doi.org/10.1186/1471-2288-12-181

Tong, A., Sainsbury, P., \& Craig, G. (2007). Consolidated criteria for reporting qualitative research (COREQ): A 32-item checklist for interviews and focus groups. International Journal for Quality in Health Care, 19(6), 349-357.

Turner, L., Shamseer, L., Altman, D.G., Weeks, L., Peters, J., Kober, T.,...Moher, D. (2012). Consolidated standards of reporting trials (CONSORT) and the completeness of reporting of randomised controlled trials (RCTs) published in medical journals. Cochrane Database Systematic Reviews 2012 Nov 14;11:MR000030. doi: 10.1002/14651858.MR000030.pub2.

Vandenbroucke, J. P., von Elm, E., Altman, D. G., Gøtzsche, P. C., Mulrow, C. D., Pocock, S. J., ... Strobe Initiative (2007). Strengthening the Reporting of Observational Studies in Epidemiology (STROBE): Explanation and Elaboration. PLOS Med, 4(10), e297. http://doi.org/10.1371/journal.pmed.0040297

Whiffin, C. J., \& Hasselder, A. (2013). Making the link between critical appraisal, thinking and analysis. British Journal of Nursing, 22(14), 831-835. 
Table 1

\section{Appendix 1}

\section{Selected Critical Appraisal Tools}

Directions: 1) Locate the type of evidence you would like to evaluate in the left column and read across the rows to identity an appropriate critical appraisal tool. 2) For information on accessing the full text of a tool and to see an example of its use, see Table 2 .

\begin{tabular}{|c|c|c|c|c|c|c|c|c|c|}
\hline $\begin{array}{l}\text { Name of } \\
\text { Rating Scale } \\
\text { or Checklist/ } \\
\text { Type of } \\
\text { Evidence }\end{array}$ & $\begin{array}{c}\text { AGREE II } \\
\text { (Brouwers } \\
\text {, et al., } \\
\text { 2010) }\end{array}$ & $\begin{array}{c}\text { CASP } \\
\text { checklis } \\
t \\
(2017)\end{array}$ & $\begin{array}{c}\text { Cochran } \\
\text { e } \\
\text { Risk of } \\
\text { Bias } \\
\text { Tool } \\
\text { (Higgins } \\
\text { \& Green, } \\
\text { 2011) }\end{array}$ & $\begin{array}{c}\text { *EPQA } \\
\text { Guidelines } \\
\text { (Lee, } \\
\text { Johnson, } \\
\text { Newhouse } \\
\text { \& } \\
\text { Warren, } \\
2013 \text { ) }\end{array}$ & $\begin{array}{c}\text { GRADE } \\
\text { (Dijkers } \\
\text { 2013) }\end{array}$ & $\begin{array}{c}\text { JBI } \\
\text { Checklist } \\
\text { s } \\
(2016)\end{array}$ & $\begin{array}{c}\text { Johns } \\
\text { Hopkins } \\
\text { Research } \\
\text { Evidence } \\
\text { Appraisa } \\
1 \text { Tool } \\
\text { (Dearholt } \\
\text { \& Dang, } \\
\text { 2012) }\end{array}$ & $\begin{array}{c}\text { Johns } \\
\text { Hopkins } \\
\text { Non- } \\
\text { Research } \\
\text { Evidence } \\
\text { Appraisa } \\
1 \text { Tool } \\
\text { (Dearholt } \\
\text { \& Dang, } \\
\text { 2012) }\end{array}$ & $\begin{array}{c}\text { Rapid } \\
\text { Critical } \\
\text { Appraisal } \\
\text { Checklist } \\
\text { s } \\
\text { (Melnyk } \\
\& \\
\text { Fineout- } \\
\text { Overholt, } \\
\text { 2015) }\end{array}$ \\
\hline $\begin{array}{l}\text { Developed } \\
\text { for use in } \\
\text { Evidence- } \\
\text { Based } \\
\text { Practice } \\
\end{array}$ & $\mathrm{N}$ & $\mathrm{N}$ & $\mathrm{N}$ & $\mathrm{Y}$ & $\mathrm{N}$ & $\mathrm{Y}$ & $\mathrm{Y}$ & $\mathrm{Y}$ & $\mathrm{Y}$ \\
\hline $\begin{array}{l}\text { Meta- } \\
\text { analysis }\end{array}$ & & & & & & $\mathrm{X}$ & $\mathrm{X}$ & & \\
\hline $\begin{array}{l}\text { Systematic } \\
\text { Review }\end{array}$ & & $X$ & & & $X$ & $X$ & & $\mathrm{X}$ & $X$ \\
\hline $\begin{array}{l}\text { Literature } \\
\text { Review }\end{array}$ & & & & & & & & $X$ & \\
\hline $\begin{array}{l}\text { Randomized } \\
\text { Controlled } \\
\text { Trial }\end{array}$ & & $X$ & $\mathrm{X}$ & & & $\mathrm{X}$ & $X$ & & $X$ \\
\hline $\begin{array}{l}\text { Cohort } \\
\text { Study }\end{array}$ & & $X$ & & & & $X$ & $X$ & & $X$ \\
\hline $\begin{array}{l}\text { Case-Control } \\
\text { Study }\end{array}$ & & $X$ & & & & $X$ & & $\mathrm{X}$ & $\mathrm{X}$ \\
\hline $\begin{array}{l}\text { Meta- } \\
\text { Synthesis }\end{array}$ & & & & & & & $X$ & & \\
\hline $\begin{array}{l}\text { Qualitative } \\
\text { Study }\end{array}$ & & $X$ & & & & $\mathrm{X}$ & $X$ & & $\mathrm{X}$ \\
\hline $\begin{array}{l}\text { Expert } \\
\text { Opinion }\end{array}$ & & & & & & $\mathrm{X}$ & & $X$ & \\
\hline $\begin{array}{l}\text { Evidence- } \\
\text { Based } \\
\text { Practice } \\
\text { Project } \\
\end{array}$ & & & & $X$ & & & & & $\mathrm{X}$ \\
\hline $\begin{array}{l}\text { Quality } \\
\text { Improvemen } \\
\text { t Project }\end{array}$ & & & & & & & & & $X$ \\
\hline $\begin{array}{l}\text { Clinical } \\
\text { Practice } \\
\text { Guideline }\end{array}$ & $X$ & $X$ & & & $\mathrm{X}$ & & & $X$ & $\mathrm{X}$ \\
\hline
\end{tabular}

(*developed to be both a critical appraisal tool and reporting guideline) 
Appendix 2

Table 2

Accessing Critical Appraisal Tools and Examples of their Use

\begin{tabular}{|c|c|c|}
\hline \multirow[t]{2}{*}{ Agree II } & $\begin{array}{l}\text { Full } \\
\text { Text }\end{array}$ & http://www.agreetrust.org/resource-centre/agree-reporting-checklist/ \\
\hline & $\begin{array}{l}\text { Examp } \\
\text { le }\end{array}$ & $\begin{array}{l}\text { Tremblay, M. S., LeBlanc, A. G., Janssen, I., Kho, M. E., Hicks, A., Murumets, K., ... } \\
\text { Duggan, M. (2011). Canadian sedentary behaviour guidelines for children and youth. } \\
\text { Applied Physiology, Nutrition and Metabolism, 36(1), 59-64. doi:10.1139/H11-012 }\end{array}$ \\
\hline \multirow{2}{*}{$\begin{array}{l}\text { CASP } \\
\text { Checklists } \\
: \\
\text { Qualitativ } \\
\mathrm{e}\end{array}$} & $\begin{array}{l}\text { Full } \\
\text { Text }\end{array}$ & http://www.casp-uk.net/\#!casp-tools-checklists/c18f8 \\
\hline & $\begin{array}{l}\text { Examp } \\
\text { le }\end{array}$ & $\begin{array}{l}\text { Masood, M., Thaliath, E. T., Bower, E. J., \& Newton, J. T. (2011). An appraisal of the } \\
\text { quality of published qualitative dental research. Community Dentistry and Oral } \\
\text { Epidemiology, 39(3), 193-203. doi:10.1111/j.1600-0528.2010.00584.x }\end{array}$ \\
\hline \multirow{2}{*}{$\begin{array}{l}\text { CASP } \\
\text { Checklists } \\
: \\
\text { Quantitati } \\
\text { ve }\end{array}$} & $\begin{array}{l}\text { Full } \\
\text { Text }\end{array}$ & http://www.casp-uk.net/\#!casp-tools-checklists/c18f8 \\
\hline & $\begin{array}{l}\text { Examp } \\
\text { le }\end{array}$ & $\begin{array}{l}\text { Smith, T. O., Walker, J., \& Russell, N. (2007). Outcomes of medial patellofemoral ligament } \\
\text { reconstruction for patellar instability: A systematic review. Knee Surgery, Sports } \\
\text { Traumatology, Arthroscopy, 15(11), 1301-1314. doi:10.1007/s00167-007-0390-0 }\end{array}$ \\
\hline \multirow{2}{*}{$\begin{array}{l}\text { Cochrane } \\
\text { Risk of } \\
\text { Bias } \\
\text { Tool }\end{array}$} & $\begin{array}{l}\text { Full } \\
\text { Text }\end{array}$ & $\begin{array}{l}\text { http://handbook.cochrane.org/chapter } 8 / \text { table } 85 \text { a the cochrane collaborations tool for } \\
\text { assessing.htm }\end{array}$ \\
\hline & $\begin{array}{l}\text { Examp } \\
\text { le }\end{array}$ & $\begin{array}{l}\text { van Esch, B. F., Stegeman, I., \& Smit, A. L. (2017). Comparison of laryngeal mask airway } \\
\text { vs tracheal intubation: A systematic review on airway complications. Journal of Clinical } \\
\text { Anesthesia, 36, 142-150. doi:10.1016/j.jclinane.2016.10.004 }\end{array}$ \\
\hline \multirow[t]{2}{*}{$\begin{array}{l}\text { EPQA } \\
\text { Guideline } \\
\text { s }\end{array}$} & $\begin{array}{l}\text { Full } \\
\text { Text }\end{array}$ & $\begin{array}{l}\text { Lee, M. C., Johnson, K. L., Newhouse, R. P., \& Warren, J. I. (2013). Evidence-based } \\
\text { Practice Process Quality Assessment: EPQA Guidelines. Worldviews on Evidence-Based } \\
\text { Nursing, 10(3), 140-149. http://doi.org/10.1111/j.1741-6787.2012.00264.x }\end{array}$ \\
\hline & $\begin{array}{l}\text { Examp } \\
\text { le }\end{array}$ & $\begin{array}{l}\text { Milner, K. A. (2014). } 10 \text { steps from EBP project to publication. Nursing, 44(11), 53-56. } \\
\text { doi:10.1097/01.NURSE.0000454954.80525.8c }\end{array}$ \\
\hline \multirow[t]{2}{*}{ GRADE } & $\begin{array}{l}\text { Full } \\
\text { Text }\end{array}$ & http://www.gradeworkinggroup.org/ \\
\hline & $\begin{array}{l}\text { Examp } \\
\text { le }\end{array}$ & $\begin{array}{l}\text { Dellinger, R. P., Levy, M. M., Rhodes, A., Annane, D., Gerlach, H., Opal, S. M., . . } \\
\text { Zimmerman, J. L. (2013). Surviving sepsis campaign: International guidelines for } \\
\text { management of severe sepsis and septic shock: 2012. Critical Care Medicine, 41(2), 580- } \\
\text { 637. doi:10.1097/CCM.0b013e31827e83af }\end{array}$ \\
\hline \multirow{2}{*}{$\begin{array}{l}\text { Joanna } \\
\text { Briggs } \\
\text { Institute } \\
\text { Critical } \\
\text { Appraisal } \\
\text { Tools } \\
\end{array}$} & $\begin{array}{l}\text { Full } \\
\text { Text }\end{array}$ & http://joannabriggs.org/research/critical-appraisal-tools.html \\
\hline & $\begin{array}{l}\text { Examp } \\
\text { le }\end{array}$ & $\begin{array}{l}\text { Paton, J., Hatton, A. L., Rome, K., \& Kent, B. (2016). Effects of foot and ankle devices on } \\
\text { balance, gait and falls in adults with sensory perception loss: A systematic review. JBI } \\
\text { Database of Systematic Reviews and Implementation Reports, 14(12), 127-162. } \\
\text { doi:10.11124/JBISRIR-2016-003229 }\end{array}$ \\
\hline \multirow{2}{*}{$\begin{array}{l}\text { Johns } \\
\text { Hopkins } \\
\text { Research } \\
\text { Evidence } \\
\text { Appraisal } \\
\text { Tool }\end{array}$} & $\begin{array}{l}\text { Full } \\
\text { Text }\end{array}$ & $\begin{array}{l}\text { http://www.hopkinsmedicine.org/evidence-based- } \\
\text { practice/ docs/appendix e research evidence appraisal tool.pdf }\end{array}$ \\
\hline & $\begin{array}{l}\text { Examp } \\
\text { le }\end{array}$ & $\begin{array}{l}\text { Santos, S C V O, Woith, W., Freitas, M. I. P., \& Zeferino, E. B. B. (2016). Methods to } \\
\text { determine the internal length of nasogastric feeding tubes: An integrative review. } \\
\text { International Journal of Nursing Studies, 61, 95-103. doi:10.1016/j.ijnurstu.2016.06.004 }\end{array}$ \\
\hline \multirow{2}{*}{$\begin{array}{l}\text { Johns } \\
\text { Hopkins } \\
\text { Non- }\end{array}$} & $\begin{array}{l}\text { Full } \\
\text { Text }\end{array}$ & $\begin{array}{l}\text { http://www.hopkinsmedicine.org/evidence-based- } \\
\text { practice/ docs/appendix f nonresearch evidence appraisal tool.pdf }\end{array}$ \\
\hline & Examp & Gutierrez, E., Silbert-Flagg, J., \& Vohra, S. (2014). Natural health product use and \\
\hline
\end{tabular}




\begin{tabular}{|l|l|l|}
\hline $\begin{array}{l}\text { Research } \\
\begin{array}{l}\text { Evidence } \\
\text { Appraisal } \\
\text { Tool }\end{array}\end{array}$ & $\begin{array}{l}\text { le of } \\
\text { tool in } \\
\text { use }\end{array}$ & $\begin{array}{l}\text { management in pediatrics: An integrative review. European Journal of Integrative } \\
\text { Medicine, 6(2), 226-233. doi:10.1016/j.eujim.2013.12.020 }\end{array}$ \\
\hline $\begin{array}{l}\text { Rapid } \\
\begin{array}{l}\text { Critical } \\
\text { Appraisal } \\
\text { Checklists }\end{array}\end{array}$ & $\begin{array}{l}\text { Full } \\
\text { Text }\end{array}$ & $\begin{array}{l}\text { Found in: Melnyk, B. M., \& Fineout-Overholt, E. (2015). Evidence-based practice in } \\
\text { nursing and healthcare: A guide to best practice. Philadelphia: Wolters Kluwer Health. }\end{array}$ \\
\cline { 2 - 3 } & $\begin{array}{l}\text { Examp } \\
\text { lo of in } \\
\text { use }\end{array}$ & $\begin{array}{l}\text { Hoffman Snyder, C. R., \& Facchiano, L. (2011). An evidence-based critical appraisal of a } \\
\text { topic: Effectiveness of high dose donepezil for advanced Alzheimer's disease. Journal for } \\
\text { Nurse Practitioners, 7(3), 201-206. doi:10.1016/j.nurpra.2011.01.018 }\end{array}$ \\
\hline
\end{tabular}


Table 3

\section{Appendix 3}

\section{Selected Reporting Guidelines}

Directions: Locate the type of evidence you are disseminating in the left column and read across the rows to identify an appropriate reporting guideline.

\begin{tabular}{|c|c|c|c|c|c|c|c|c|}
\hline $\begin{array}{l}\text { Name of } \\
\text { Reporting } \\
\text { Guideline/ } \\
\text { Type of } \\
\text { Evidence }\end{array}$ & $\begin{array}{c}\text { AGREE } \\
\text { Reporting } \\
\text { Checklist } \\
\text { (Brouwers, } \\
\text { Kerkvliet, } \\
\text { \& Spithoff, } \\
\text { 2016) }\end{array}$ & $\begin{array}{c}\text { CONSORT } \\
\text { Checklist } \\
\text { \& Flow } \\
\text { Diagram } \\
\text { (Turner, et } \\
\text { al., 2012) }\end{array}$ & $\begin{array}{l}\text { COREQ } \\
\text { (Tong, } \\
\text { Sainsbury, } \\
\text { \& Craig, } \\
\text { 2007) }\end{array}$ & $\begin{array}{c}\text { *EPQA } \\
\text { Guidelines } \\
\text { (Lee, } \\
\text { Johnson, } \\
\text { Newhouse, } \\
\text { \& Warren, } \\
\text { 2013) }\end{array}$ & $\begin{array}{c}\text { ENTREQ } \\
\text { (Tong, } \\
\text { Flemming, } \\
\text { McInnes, } \\
\text { Oliver, \& } \\
\text { Craig, } \\
\text { 2012) }\end{array}$ & $\begin{array}{c}\text { PRISMA } \\
\text { Guidelines } \\
\text { (Moher, } \\
\text { 2012) }\end{array}$ & $\begin{array}{c}\text { SQUIRE } \\
2.0 \\
\text { Guidelines } \\
\text { (Ogrinc, } \\
\text { Davies, } \\
\text { Goodman, } \\
\text { Batalden, } \\
\text { Davidoff, } \\
\text { \& Stevens, } \\
\text { 2015) }\end{array}$ & $\begin{array}{c}\text { STROBE } \\
\text { (Vandenbroucket } \\
\text { al., 2007) }\end{array}$ \\
\hline $\begin{array}{l}\text { Meta- } \\
\text { analysis }\end{array}$ & & & & & & $\mathrm{X}$ & & \\
\hline $\begin{array}{l}\text { Systematic } \\
\text { Review }\end{array}$ & & & & & & $\mathrm{X}$ & & \\
\hline $\begin{array}{l}\text { Randomized } \\
\text { Controlled } \\
\text { Trial }\end{array}$ & & $X$ & & & & $\mathrm{X}$ & & \\
\hline $\begin{array}{l}\text { Cohort } \\
\text { Study }\end{array}$ & & & & & & & & $\mathrm{X}$ \\
\hline $\begin{array}{l}\text { Case-Control } \\
\text { Study }\end{array}$ & & & & & & & & $\mathrm{X}$ \\
\hline $\begin{array}{l}\text { Cross- } \\
\text { Sectional } \\
\text { Study }\end{array}$ & & & & & & & & $\mathrm{X}$ \\
\hline $\begin{array}{l}\text { Meta- } \\
\text { Synthesis }\end{array}$ & & & & & $\mathrm{X}$ & & & \\
\hline $\begin{array}{l}\text { Qualitative } \\
\text { Study }\end{array}$ & & & $\mathrm{X}$ & & & & & \\
\hline $\begin{array}{l}\text { Evidence- } \\
\text { Based } \\
\text { Practice } \\
\text { Project } \\
\end{array}$ & & & & $\mathrm{X}$ & & & & \\
\hline $\begin{array}{l}\text { Quality } \\
\text { Improvement } \\
\text { Project }\end{array}$ & & & & & & & $\mathrm{X}$ & \\
\hline $\begin{array}{l}\text { Clinical } \\
\text { Practice } \\
\text { Guideline }\end{array}$ & $\mathrm{X}$ & & & & & & & \\
\hline
\end{tabular}

(*developed to be both a critical appraisal tool and reporting guideline) 
Table 4

Appendix 4

Accessing Reporting Guidelines and Examples of their Use

\begin{tabular}{|c|c|c|}
\hline \multirow{2}{*}{$\begin{array}{l}\text { Agree } \\
\text { Reporting } \\
\text { Checklist }\end{array}$} & Full Text & http://www.agreetrust.org/resource-centre/agree-reporting-checklist// \\
\hline & Example & $\begin{array}{l}\text { Deery, C. (2017). Clinical practice guidelines proposed the use of pit and fissure } \\
\text { sealants to prevent and arrest noncavitated carious lesions. Journal of Evidence- } \\
\text { Based Dental Practice, 17(1), 48-50. doi:10.1016/j.jebdp.2017.01.008 }\end{array}$ \\
\hline \multirow[t]{2}{*}{ CONSORT } & Full Text & http://www.equator-network.org/reporting-guidelines/consort// \\
\hline & Example & $\begin{array}{l}\text { O’Brien, K., Bracht, M., Robson, K., Ye, X. Y., Mirea, L., Cruz, M., .. Lee, S. K. } \\
\text { (2015). Evaluation of the family integrated care model of neonatal intensive care: A } \\
\text { cluster randomized controlled trial in canada and australia. BMC } \\
\text { Pediatrics, } 15 \text { doi:10.1186/s12887-015-0527-0 }\end{array}$ \\
\hline \multirow[t]{2}{*}{ COREQ } & Full Text & http://www.equator-network.org/reporting-guidelines/coreq/ \\
\hline & Example & $\begin{array}{l}\text { Alnahedh, T., Suttle, C. M., Alabdelmoneam, M., \& Jalbert, I. (2015). Optometrists } \\
\text { show rudimentary understanding of evidence-based practice but are ready to embrace } \\
\text { it: Can barriers be overcome? Clinical and Experimental Optometry, 98(3), 263-272. } \\
\text { doi:10.1111/cxo.12238 }\end{array}$ \\
\hline \multirow[t]{2}{*}{$\begin{array}{l}\text { EPQA } \\
\text { Guidelines }\end{array}$} & Full Text & $\begin{array}{l}\text { Lee, M. C., Johnson, K. L., Newhouse, R. P., \& Warren, J. I. (2013). Evidence-based } \\
\text { Practice Process Quality Assessment: EPQA Guidelines. Worldviews on Evidence- } \\
\text { Based Nursing, 10(3), 140-149. http://doi.org/10.1111/j.1741-6787.2012.00264.x }\end{array}$ \\
\hline & Example & $\begin{array}{l}\text { Milner, K. A. (2014). } 10 \text { steps from EBP project to publication. Nursing, 44(11), 53- } \\
\text { 56. doi:10.1097/01.NURSE.0000454954.80525.8c }\end{array}$ \\
\hline \multirow[t]{2}{*}{ ENTREQ } & Full Text & http://www.equator-network.org/reporting-guidelines/entreq/ \\
\hline & Example & $\begin{array}{l}\text { Hall, H., Leach, M., Brosnan, C., \& Collins, M. (2017). Nurses attitudes towards } \\
\text { complementary therapies: A systematic review and meta-synthesis. International } \\
\text { Journal of Nursing Studies, 69, 47-56. doi:10.1016/j.ijnurstu.2017.01.008 }\end{array}$ \\
\hline \multirow{2}{*}{$\begin{array}{l}\text { PRISMA } \\
\text { Statement }\end{array}$} & Full Text & http://www.equator-network.org/reporting-guidelines/prisma/ \\
\hline & Example & $\begin{array}{l}\text { Minges, K. E., \& Redeker, N. S. (2016). Delayed school start times and adolescent } \\
\text { sleep: A systematic review of the experimental evidence. Sleep Medicine } \\
\text { Reviews, 28, 82-91. doi:10.1016/j.smrv.2015.06.002 }\end{array}$ \\
\hline \multirow[t]{2}{*}{ SQUIRE 2.0} & Full Text & http://www.equator-network.org/reporting-guidelines/squire/ \\
\hline & $\begin{array}{l}\text { Example of } \\
\text { tool in use }\end{array}$ & $\begin{array}{l}\text { Repique, R. J. R., Vernig, P. M., Lowe, J., Thompson, J. A., \& Yap, T. L. (2016). } \\
\text { Implementation of a recovery-oriented training program for psychiatric nurses in the } \\
\text { inpatient setting: A mixed-methods hospital quality improvement study. Archives of } \\
\text { Psychiatric Nursing, 30(6), 722-728. doi:10.1016/j.apnu.2016.06.003 }\end{array}$ \\
\hline \multirow{2}{*}{$\begin{array}{l}\text { STROBE } \\
\text { Guidelines }\end{array}$} & Full Text & http://www.equator-network.org/reporting-guidelines/strobe/ \\
\hline & $\begin{array}{l}\text { Example of } \\
\text { tool in use }\end{array}$ & $\begin{array}{l}\text { Walston, J. M., Cabrera, D., Bellew, S. D., Olive, M. N., Lohse, C. M., \& Bellolio, } \\
\text { M. F. (2016). Vital signs predict rapid-response team activation within twelve hours } \\
\text { of emergency department admission. Western Journal of Emergency Medicine: } \\
\text { Integrating Emergency Care with Population Health, 17(3), 324-330. } \\
\text { doi:10.5811/westjem.2016.2.28501 }\end{array}$ \\
\hline
\end{tabular}

